\title{
Association of the IFNAR1-17470 and IL-10-592 cytokine variants with susceptibility to chronic hepatitis $B$ viral infections in a Chinese population
}

Y. Xiang ${ }^{1}$, S.F. Huang ${ }^{1}$, J.R. Xia ${ }^{1}$, D.Q. Ye ${ }^{1}$, P. Chen ${ }^{1}$, S.S. Yang ${ }^{1}$, S. Sun ${ }^{1}$ X.F. Lai ${ }^{1}$ and L.P. Zhang ${ }^{1,2}$

${ }^{1}$ Department of Laboratory Medicine,

The First Affiliated Hospital of Chongqing Medical University, Yuzhong District, Chongqing, China

${ }^{2}$ Department of Clinical Laboratory,

The First Affiliated Hospital of Chongqing Medical University,

Yuzhong District, Chongqing, China

Corresponding author: L.P. Zhang

E-mail: lipingzhang723@163.com

Genet. Mol. Res. 13 (4): 9187-9195 (2014)

Received May 28, 2014

Accepted August 2, 2014

Published November 7, 2014

DOI http://dx.doi.org/10.4238/2014.November.7.5

\begin{abstract}
An association between the sequence variants of cytokine genes and various clinical outcomes in subjects infected with the hepatitis B virus (HBV) has been demonstrated. However, the results are inconsistent and inconclusive. Further studies in other populations and the evaluation of a greater number of individuals may contribute to a better understanding of the influence of the cytokine genetic variants on the evolution of HBV infections. This study was performed to explore the relationships between the sequence variants of TNF-A-308, IFNARI-17470, and IL-10-592 and the susceptibility to chronic hepatitis $\mathrm{B}$ (CHB) in a Chinese population. A total of 160 patients with CHB and 124 individuals who had spontaneously
\end{abstract}


recovered (SR) from hepatitis B were enrolled in the present study. The variants at TNF-A-308, IFNAR1-17470, and IL-10-592 were determined by PCR-restriction fragment length polymorphism analysis and were confirmed by bidirectional DNA sequencing. Significant differences were found between the CHB and the SR groups in the frequency and distribution of the genotypes of both IFNAR1-17470 and $I L-10-592$ genes. In comparison with the CHB patients with the IFNAR1-17470 G/G variant, the odds ratio (OR) of the CHB patients with the IFNARI-17470 C/C variant developing chronic hepatitis was $2.06(95 \% \mathrm{CI}=1.03-4.14)$. In addition, the OR of the patients with CHB having the IL-10-592 C/C variant developing chronic hepatitis was $2.77(95 \% \mathrm{CI}=1.13-4.57)$ when compared with that of the patients with the $I L-10-592 \mathrm{~A} / \mathrm{A}$ variant. In conclusion, sequence variants of both the IFNARI-17470 and IL-10-592 genes were correlated with susceptibility to CHB.

Key words: Hepatitis B virus; Chronic hepatitis B; Sequence variants; IFNAR1-17470; IL-10-592

\section{INTRODUCTION}

Infections with the hepatitis B virus (HBV) are an important worldwide public health problem (Kao and Chen, 2002). Variable clinical conditions result from exposure to the HBV, such as a spontaneous recovery from acute hepatitis, asymptomatic carrier status, chronic hepatitis, liver cirrhosis, and hepatocellular carcinoma. In addition to the pathogenicity of the virus, immunological and genetic factors of the host influence the diverse spectrum of disease after infection with the HBV (Guidotti and Chisari, 2001; Jung and Pape, 2002; Kao, 2002). Sequence variants of a variety of genes in the host have been implicated in the diversity of the clinical course of HBV infections (Kim et al., 2003; Deng et al., 2004; Thio et al., 2004; Wang et al., 2004).

Cytokines play an important role in the anti-viral defense system through direct inhibition of viral replication and indirectly by determining the predominant pattern of the host immune response. Sequence variations in the coding, promoter, and untranslated regions of cytokine genes may alter the expression and activity of their respective proteins (Hollegaard and Bidwell, 2006). Cross-sectional studies have demonstrated an association between the sequence variants of cytokine genes and various clinical outcomes in subjects infected with the HBV (Migita et al., 2005; Tseng et al., 2006; Cheong et al., 2006). However, the results are inconsistent and inconclusive.

Tumor necrosis factor- $\alpha$ (TNF- $\alpha$ ) plays a pivotal role in viral clearance and the host immune response to the $\mathrm{HBV}$, and the TNF- $\alpha$ production capacity in individuals is influenced primarily by their genetic background (Kim et al., 2003). The $T N F-A$ and $T N F-B$ genes are located between the human leukocyte antigens $h L A-B$ and $h L A-D R$ on $6 \mathrm{p} 21.3$. The base replacement of $\mathrm{G}$ to $\mathrm{A}$ at site -308 leads to sequence variants in its promoter region. Several studies have reported conflicting results regarding the effect of the $T N F-\alpha-308$ sequence variants on chronic hepatitis B (CHB) viral infections (Höhler et al., 1998; Du et al., 2006; Basturk et al., 2008). 
The endogenous production of interferon serves as an initial defense mechanism against viral infection, and in clinical practice, interferon- $\alpha$ (IFN- $\alpha)$ treatment remains the mainstay of treatment for active hepatitis B. It has been demonstrated that cell surface IFNAR1 expression levels directly affect the efficiency of IFN- $\alpha$-induced activity (Dondi et al., 2001). The corresponding IFNARI gene is situated on chromosome 21q22.11. Several sequence variants in the IFNAR1 promoter region have been reported (Aucan et al., 2003; Yoshida et al., 2005), and some variants were associated with IFNAR1 expression levels (Zhou et al., 2009a,b).

Interleukin 10 (IL-10) is another important cytokine that displays anti-inflammatory and anti-fibrotic functions (Lu et al., 2010). The $I L-10$ gene is located on chromosome 1. Sequence variations in the $I L-10$ promoter region can affect IL-10 production and increase susceptibility to inflammatory diseases. The proximal promoter contains 3 common sequence variants at positions $-1082,-819$, and -592 relative to the transcription start site (Yan et al., 2009).

In summary, sequence variations in the promoter regions of the TNF- $\alpha, I F N A R 1$, and $I L-10$ genes contribute to the variable clinical outcomes of an HBV infection. Further studies in different populations and the evaluation of a greater number of individuals could contribute to a better understanding of the influence of the cytokine sequence variants on the evolution of HBV infections. Thus, the present study was initiated to genotype the TNF-A-308, IFNARI-17470, and $I L-10-592$ sequence variants in a southwestern Chinese population and to validate the association between genetic variations of these genes and the clinical presentation of HBV infections.

\section{MATERIAL AND METHODS}

\section{Study subjects and sample collection}

The study participants were composed of 160 patients with CHB and 124 individuals who had spontaneously recovered (SR) from hepatitis B. Written informed consent was obtained from all patients. Blood samples were collected from the CHB patients at the First Affiliated Hospital of Chongqing Medical University. As a control group, 124 spontaneously recovered individuals who had cleared a previous HBV infection, for example, subjects who were HB$\mathrm{sAg}^{-}$and anti-HBc IgG+, were enrolled in the study. The study protocol conformed to the ethical guidelines of the 1975 Declaration of Helsinki as reflected in an a priori approval by the human research committee of the First Affiliated Hospital of Chongqing Medical University. The status of $\mathrm{HBsAg}, \mathrm{HBeAg}$, and $\mathrm{HBcAb}$ in the serum of all of the individuals was quantitatively determined with a chemiluminescence assay (Abbott Architect). The detailed demographic and serological profiles of the CHB patients and the SR control subjects are shown in Table 1.

Table 1. Demographic and serological profiles of the chronic hepatitis B (CHB) patients and the spontaneously
recovered (SR) control subjects.
\begin{tabular}{lrcccccc}
\hline Groups & No. & Male/female & HBsAg & Anti-HBs & HBeAg & Anti-HBe & Anti-HBc \\
\hline CHB & 60 & $31 / 29$ & + & - & + & - & + \\
& 100 & $39 / 61$ & + & - & - & + & + \\
SR & 124 & $64 / 60$ & - & - & - & - & + \\
\hline
\end{tabular}

\section{Genotyping of sequence variants}

Genomic DNA was isolated from whole blood by using a commercial DNA purification 
kit (Qiagen, Hilden, Germany). The sequence variants of TNF-A-308, IFNAR1-17470, and $I L$ 10-592 were determined for all subjects by performing a polymerase chain reaction-restriction fragment length polymorphism (PCR-RFLP) analysis. The results were confirmed with bidirectional DNA sequencing. The primer sequences and PCR conditions used are listed in Table 2. The PCR amplicons were digested with restriction enzymes and the products were run on a $3 \%$ agarose gel.

Table 2. Primer sequences and amplification conditions of the genes.
\begin{tabular}{llccccc}
\hline Genes (variants) & Primer sequence (5'-3') & Initial denaturation & Denaturation & Annealing & Extension & Cycling No. \\
\hline TNF-A-308 & F: AGGCAATAGGTTTTGAGGGCCAT & $94^{\circ} \mathrm{C}$ & $94^{\circ} \mathrm{C}$ & $58^{\circ} \mathrm{C}$ & $72^{\circ} \mathrm{C}$ & 35 \\
(G-A) & R: TCCTCCCTGCTCCGATTCCG & $5 \mathrm{~min}$ & $1 \mathrm{~min}$ & $1 \mathrm{~min}$ & $1 \mathrm{~min}$ & \\
IL-10-592 & F: CCTAGGTCACAGTGACGTGG & $94^{\circ} \mathrm{C}$ & $94^{\circ} \mathrm{C}$ & $60^{\circ} \mathrm{C}$ & $72^{\circ} \mathrm{C}$ & 35 \\
(A-C) & R: GGTGAGCACTACCTGACTAGC & $2 \mathrm{~min}$ & $30 \mathrm{~s}$ & $45 \mathrm{~s}$ & $1 \mathrm{~min}$ & \\
IFNAR1-17470 & F: CTTTCCCTGTAGTAGTGGTTCT & $95^{\circ} \mathrm{C}$ & $95^{\circ} \mathrm{C}$ & $60^{\circ} \mathrm{C}$ & $72^{\circ} \mathrm{C}$ & 35 \\
(G-C) & R: CTGTAGTGAGCCGTGATTGT & $5 \mathrm{~min}$ & $30 \mathrm{~s}$ & $30 \mathrm{~s}$ & $30 \mathrm{~s}$ & \\
\hline
\end{tabular}

\section{Statistical analyses}

All genotype and allele frequencies were determined by counting their frequency and verifying that they were consistent with the Hardy-Weinberg law. Comparisons were made with a chi-squared $\left(\chi^{2}\right)$ test and an independent samples $t$-test. Odds ratios (ORs) were determined with binary logistic regressions (SPSS, version 13.0) for each haplotype, allele, and genotype. The OR was used to reflect the likelihood of carrying a specific genetic sequence variant if a subject was persistently infected with the HBV. A genetic marker with an OR value lower or higher than 1 signified that the marker conferred resistance or susceptibility, respectively, to chronic $\mathrm{HBV}$ infection. A P value $<0.05$ was considered to be statistically significant.

\section{RESULTS}

\section{General clinical characteristics}

The clinical details and the results of the biochemical analyses from the CHB and SR subjects at the time of the study are shown in Tables 1 and 3 . While no significant differences were found in the age, gender, or alanine aminotransferase (ALT) and aspartate aminotransferase (AST) levels between the CHB and the SR subjects, there were significant differences between the 2 groups in the antibody statuses for HBsAg and $\mathrm{HBcAb}$ (Table 3 ).

\begin{tabular}{|c|c|c|c|}
\hline & CHB group $(\mathrm{N}=160)$ & SR control $(\mathrm{N}=124)$ & $\mathrm{P}$ \\
\hline Age & $42.15 \pm 15.15$ & $42.95 \pm 9.53$ & $>0.05$ \\
\hline \multicolumn{4}{|l|}{ Gender } \\
\hline Male & $70(44 \%)$ & $64(52 \%)$ & $>0.05$ \\
\hline Female & $90(56 \%)$ & $60(48 \%)$ & \\
\hline $\operatorname{ALT}(\mathrm{IU} / \mathrm{L})$ & $61.75 \pm 232.35$ & $38.15 \pm 64.12$ & $>0.05$ \\
\hline AST (IU/L) & $52.04 \pm 143.92$ & $39.15 \pm 67.73$ & $>0.05$ \\
\hline HBsAg $(I U / m L)$ & $206.77 \pm 270.24$ & $0.01 \pm 001$ & $<0.05$ \\
\hline $\mathrm{HBcAb}(\mathrm{S} / \mathrm{CO})$ & $13.20 \pm 3.34$ & $4.29 \pm 2.83$ & $<0.05$ \\
\hline
\end{tabular}




\section{$T N F-A-308, I F N A R 1-17470$, and $I L-10-592$ genotyping}

The 107-bp PCR product of the $T N F-A$ gene was incubated with $N c o$ I at $37^{\circ} \mathrm{C}$ overnight. Homozygotes with the wild type A allele displayed a single band corresponding to the 107 base pair (bp) fragment. Homozygotes with the $\mathrm{G}$ allele displayed an 87-bp band, and the heterozygotes displayed both the 107- and 87-bp fragments (Figure 1A).

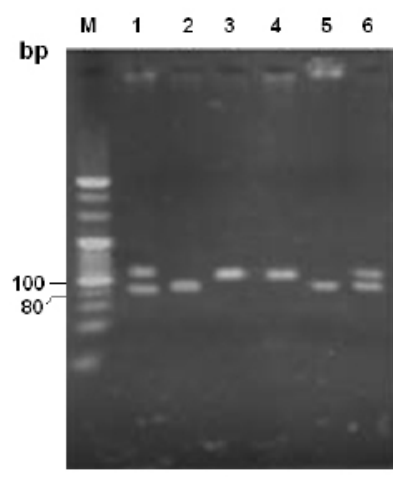

A

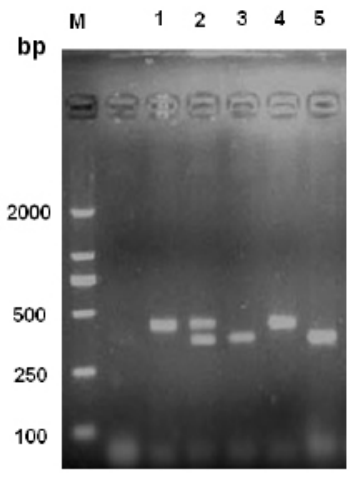

B

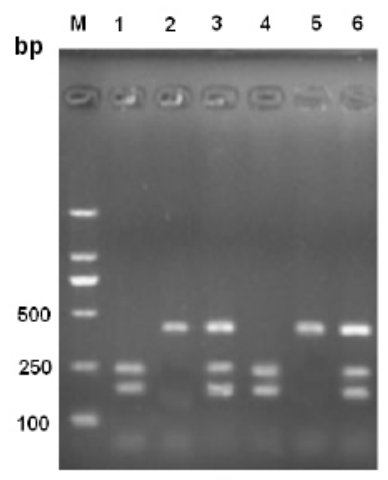

C

Figure 1. Identification of TNF-A-308, IFNA R1-17470, and IL-10-592 sequence variants by RFLP. PCR amplicons of TNF-A, IFNA R1, and IL-10 were digested with NcoI, RsaI, and BsmAI, respectively, and the representative individuals with variant genotypes were shown for each gene. A. TNF-A-308 variant: Lane $M=$ marker; lanes 1 and $6=\mathrm{G} / \mathrm{A}$ genotype; lanes 3 and $4=\mathrm{A} / \mathrm{A}$ genotype; lanes 2 and $5=\mathrm{G} / \mathrm{G}$ genotype; B. IFNAR1-17470 variant: lane $M=$ marker; lanes 1 and $4=\mathrm{C} / \mathrm{C}$ genotype; lanes 3 and $5=\mathrm{G} / \mathrm{G}$ genotype: lane $2=\mathrm{G} / \mathrm{C}$ genotype; C. IL-10592 variant: lane $M=$ marker; lanes 1 and $4=\mathrm{A} / \mathrm{A}$ genotype; lanes 2 and $5=\mathrm{C} / \mathrm{C}$ genotype; lanes 3 and $6=\mathrm{A} / \mathrm{C}$ genotype.

Incubation with $B s m \mathrm{AI}$ at $55^{\circ} \mathrm{C}$ overnight cleaved the 420-bp PCR product of the IFNAR1-17470 G/G variant into 2 fragments of 359 and $61 \mathrm{bp}$. Homozygotes with the wildtype $\mathrm{C}$ allele were undigested at the polymorphic site and yielded only 1 band of $420 \mathrm{bp}$. The $\mathrm{G} / \mathrm{C}$ heterozygotes displayed all 3 bands (Figure 1B).

In a similar manner, the amplicon of the $I L-10$ gene was digested with $R s a \mathrm{I}$ at $37^{\circ} \mathrm{C}$ overnight. The $I L-10-592 \mathrm{~A} / \mathrm{A}$ genotype generated 2 fragments of 236 and $176 \mathrm{bp}$. The $\mathrm{C} / \mathrm{C}$ genotype yielded a single 412-bp band and the A/C genotype yielded 3 bands of 412, 236, and 176 bp (Figure 1C).

All of these variants were further confirmed genetically through bi-directional DNA sequencing (data not shown).

Frequency and distribution of the genotypes and alleles of the $T N F-A-308$, IFNAR1-17470, and IL-10-592 genes in the patients with CHB and the SR control group

Chi-square tests demonstrated that all of the nine genotypes and allele frequencies were consistent with the Hardy-Weinberg law. Table 4 presents the different frequencies and distributions of the genotypes for TNF-A-308, IFNAR1-17470, and IL-10-592 in the 2 study groups. While no significant differences were found in the distribution of the $T N F-A-308$ variants between the CHB patients and the SR controls, the frequencies of the IFNARI-17470 C 
and $I L-10-592 \mathrm{C}$ alleles were significantly higher in the CHB group than in the SR control group $\left(\chi^{2}=7.90\right.$ and 6.26 , respectively, $\left.\mathrm{P}<0.05\right)$.

\begin{tabular}{|c|c|c|c|}
\hline Genotypes & $\mathrm{SR}(\mathrm{N}=124)$ & & CHB $(\mathrm{N}=160)$ \\
\hline \multicolumn{4}{|l|}{ TNF-A-308 } \\
\hline$G / G$ & $92(0.74)$ & \multirow{6}{*}{$\chi^{2}=0.27, \mathrm{P}>0.05$} & $116(0.72)$ \\
\hline$G / A$ & $28(0.22)$ & & $37(0.23)$ \\
\hline$A / A$ & $4(0.04)$ & & $7(0.05)$ \\
\hline Alleles & & & \\
\hline G & $212(0.85)$ & & $269(0.84)$ \\
\hline A & $36(0.15)$ & & $51(0.16)$ \\
\hline \multicolumn{4}{|c|}{ IFNARI-17470 } \\
\hline$G / G$ & $38(0.31)$ & \multirow{6}{*}{$\chi^{2}=7.90, P<0.05$} & $46(0.29)$ \\
\hline$G / C$ & $68(0.55)$ & & $69(0.43)$ \\
\hline$C / C$ & $18(0.14)$ & & $45(0.28)$ \\
\hline Alleles & & & \\
\hline G & $144(0.58)$ & & $161(0.50)$ \\
\hline C & $104(0.42)$ & & $159(0.50)$ \\
\hline \multicolumn{4}{|l|}{ IL-10-592 } \\
\hline$C / C$ & $16(0.13)$ & \multirow{6}{*}{$\chi^{2}=6.26, \mathrm{P}<0.05$} & $34(0.21)$ \\
\hline$A / C$ & $48(0.39)$ & & $70(0.44)$ \\
\hline$A / A$ & $60(0.48)$ & & $56(0.35)$ \\
\hline & & & \\
\hline C & $80(0.32)$ & & $138(0.43)$ \\
\hline A & $168(0.68)$ & & $182(0.57)$ \\
\hline
\end{tabular}

\section{IFNARI-17470 C/C and $I L-10-592 \mathrm{C} / \mathrm{C}$ variants were associated with susceptibility to chronic $\mathrm{HBV}$ infection}

Table 5 presents the different risks of each variant of $T N F-A-308, I F N A R 1-17470$, and $I L-10-592$ in the 2 study groups. While no significant differences between the CHB patients and the SR controls were found for the ORs of the TNF-A-308 variants, both the IFNAR1-17470 $\mathrm{C} / \mathrm{C}$ and the $I L-10-592 \mathrm{C} / \mathrm{C}$ variants were associated with a higher susceptibility to chronic HBV infections. The OR of the CHB patients with the IFNARI-17470 C/C variant developing chronic hepatitis was $2.06(95 \% \mathrm{CI}=1.03-4.14)$ in comparison with patients with the $\mathrm{G} / \mathrm{G}$ variant. Similarly, the OR of the CHB patients with the $I L-10-592 \mathrm{C} / \mathrm{C}$ variant developing chronic hepatitis was $2.77(95 \% \mathrm{CI}=1.13-4.57)$ when compared with that of the patients with the $\mathrm{A} / \mathrm{A}$ variant.

\begin{tabular}{|c|c|}
\hline Genotypes & $\begin{array}{l}\text { Risk for CHB } \\
\text { OR }(95 \% \mathrm{CI})\end{array}$ \\
\hline \multicolumn{2}{|l|}{$\overline{T N F-A-308}$} \\
\hline $\mathrm{G} / \mathrm{G}$ & 1.00 \\
\hline $\mathrm{A} / \mathrm{A}$ & $1.39(0.39-4.89)$ \\
\hline $\mathrm{A} / \mathrm{G}$ & $1.05(0.60-1.84)$ \\
\hline \multicolumn{2}{|c|}{ IFNA RI-17470 } \\
\hline $\mathrm{G} / \mathrm{G}$ & 1.00 \\
\hline $\mathrm{C} / \mathrm{C}$ & $2.06(1.03-4.14)^{\&}$ \\
\hline $\mathrm{G} / \mathrm{C}$ & $0.84(0.49-1.44)$ \\
\hline \multicolumn{2}{|l|}{$I L-10-592$} \\
\hline & 1.00 \\
\hline $\mathrm{C} / \mathrm{C}$ & $2.77(1.13-4.57)^{\&}$ \\
\hline $\mathrm{A} / \mathrm{C}$ & $1.56(0.93-2.62)$ \\
\hline
\end{tabular}




\section{DISCUSSION}

Sequence variants of a variety of cytokine genes have been implicated in the diversity of the clinical course of HBV infections. In the present study, no significant differences were found between the CHB and the SR groups in the distribution or ORs of the TNF$A-308$ variants. However, the frequencies of the IFNARI-17470 C and IL-10-592 C alleles were significantly higher in the patients with CHB than in the SR control group. Both the IFNARI $17470 \mathrm{C} / \mathrm{C}$ and $I L-10-592 \mathrm{C} / \mathrm{C}$ variants were associated with a higher susceptibility to chronic HBV infections in the Chinese population studied.

Although Basturk et al. (2008) found that the frequency of the $T N F-A-308 \mathrm{G} / \mathrm{G}$ variant in a Turkish population was significantly higher in individuals infected with the HBV than in the healthy controls, this study found no significant differences between the CHB and the SR groups in the distribution or the ORs of the $T N F-A-308$ variants. This discrepancy may be due to the different control groups used in the studies. While Basturk et al. (2008) recruited healthy individuals to use for their control group, our group recruited individuals who had spontaneously recovered from hepatitis B as controls.

The variants in the IFNARI promoter region at $-568 /-77$ and the sequence variants in the IFNARI coding region at $19158 \mathrm{C} / \mathrm{G}$ have previously been shown to be associated with a susceptibility to chronic HBV infections (Zhou et al., 2009b). Further exploration at the functional level demonstrated that a $\mathrm{C} / \mathrm{G}$ variant at 19,158 resulted in a non-synonymous substitution in the extracellular region of IFNAR1, leading to a decreased stability of the IFNAR1 protein. Moreover, a later study demonstrated that 2 linked sequence variants at -408 and -3 of the IFNARI promoter were associated with a susceptibility to chronic HBV infections (Zhou et al., 2009a). Further investigation of the functional mechanisms involved revealed that an infection with the HBV decreased the transcriptional levels of the IFNARI$3 \mathrm{~T}$ variant. Our data correlating the IFNARI-17470 C/C variant with the onset of chronic $\mathrm{HBV}$ infections are consistent with a recent study that also found that the $\mathrm{C} / \mathrm{C}$ variant of IFNAR1-17470 was present more frequently in the patients infected with HBV than in the SR controls (Song et al., 2008).

The seroconversion of HBeAg generally indicates a diminished active viral replication rate and a decrease in disease activity (Fattovich et al., 1986). A recent prospective cohort study (Wu et al., 2010) demonstrated that the $I L-10-1082 \mathrm{G} / \mathrm{G}$ variant is associated with higher serum levels of IL-10 and an early, spontaneous HBeAg seroconversion. Yan et al. (2009) have demonstrated that the CHB IL-10-592 C susceptibility allele also displayed greater transcription activity than did the $I L-10-592$ A allele. We predict that the $I L-10-592 \mathrm{C} / \mathrm{C}$ variant may also be associated with higher serum levels of IL-10, and thus, with early and spontaneous HBeAg seroconversion in patients with CHB.

In conclusion, the present study explored the relationships between the $T N F-A-308$, IFNAR1-17470, and $I L-10-592$ sequence variants and susceptibility to CHB in a southwestern Chinese population. Both the IFNARI-17470 C/C and $I L-10-592 \mathrm{C} / \mathrm{C}$ variants were associated with higher susceptibilities to chronic HBV infections. However, whether and how the IFNAR1-17470 and IL-10-592 C/C variants influence IFNAR1 and IL-10 protein expression and the response to treatment by patients with $\mathrm{CHB}$ infections remain to be elucidated. We are presently performing mutagenesis and luciferase assays to explore the functional significance of the IFNARI-17470 and $I L-10-592$ variants. 


\section{Conflicts of interest}

The authors declare no conflict of interest.

\section{ACKNOWLEDGMENTS}

Research supported partially by the National Science Foundation of China (Grant \#81071621 and \#30973378), the Natural Science Foundation of Chongqing, China (Grant CSTC, \#2009BB5257 and \#2010BB5390), and the Medical Science Foundation of the First Affiliated Hospital of Chongqing Medical University (Grant \#YXJJ 2009-12).

\section{REFERENCES}

Aucan C, Walley AJ, Hennig BJ, Fitness J, et al. (2003). Interferon- $\alpha$ receptor-1 (IFNAR1) variants are associated with protection against cerebral malaria in the Gambia. Genes Immun. 4: 275-282.

Basturk B, Karasu Z, Kilic M, Ulukaya S, et al. (2008). Association of TNF- $\alpha-308$ polymorphism with the outcome of hepatitis B virus infection in Turkey. Infect. Genet. Evol. 8: 20-25.

Cheong JY, Cho SW, Hwang IL, Yoon SK, et al. (2006). Association between chronic hepatitis B virus infection and interleukin-10, tumor necrosis factor- $\alpha$ gene promoter polymorphisms. J. Gastroenterol. Hepatol. 21: 1163-1169.

Deng G, Zhou G, Zhai Y, Li S, et al. (2004). Association of estrogen receptor $\alpha$ polymorphisms with susceptibility to chronic hepatitis B virus infection. Hepatology 40: 318-326.

Dondi E, Pattyn E, Lutfalla G, Van Ostade, X, et al. (2001). Down-modulation of type 1 interferon responses by receptor cross-competition for a shared Jak kinase. J. Biol. Chem. 276: 47004-47012.

Du T, Guo XH, Zhu XL, Li JH, et al. (2006). Association of TNF- $\alpha$ promoter polymorphisms with the outcomes of hepatitis B virus infection in Chinese Han population. J. Viral Hepat. 13: 618-624.

Fattovich G, Rugge M, Brollo L, Pontisso P, et al. (1986). Clinical, virologic and histologic outcome following seroconversion from HBeAg to anti-HBe in chronic hepatitis type B. Hepatology 6: 167-172.

Guidotti LG and Chisari FV (2001). Noncytolytic control of viral infections by the innate and adaptive immune response. Annu. Rev. Immunol. 19: 65-91.

Höhler T, Kruger A, Gerken G, Schneider PM, et al. (1998). A tumor necrosis factor- $\alpha$ (TNF- $\alpha$ ) promoter polymorphism is associated with chronic hepatitis B infection. Clin. Exp. Immunol. 111: 579-582.

Hollegaard MV and Bidwell JL (2006). Cytokine gene polymorphism in human disease: on-line databases, Supplement 3. Genes Immun. 7: 269-276.

Jung MC and Pape GR (2002). Immunology of hepatitis B infection. Lancet Infect. Dis. 2: 43-50.

Kao JH (2002). Hepatitis B viral genotypes: clinical relevance and molecular characteristics. J. Gastroenterol. Hepatol. 17: $643-650$.

Kao JH and Chen DS (2002). Global control of hepatitis B virus infection. Lancet Infect. Dis. 2: 395-403.

Kim YJ, Lee HS, Yoon JH, Kim CY, et al. (2003). Association of TNF- $\alpha$ promoter polymorphisms with the clearance of hepatitis B virus infection. Hum. Mol. Genet. 12: 2541-2546.

Lu YL, Wu X, Huang HL and Dai LC (2010). Allele polymorphisms of interleukin-10 and hepatitis B, C virus infection. Chin. Med. J. 123: 1338-1344.

Migita K, Miyazoe S, Maeda Y, Daikoku M, et al. (2005). Cytokine gene polymorphisms in Japanese patients with hepatitis B virus infection - association between TGF- $\beta 1$ polymorphisms and hepatocellular carcinoma. J. Hepatol. 42: 505-510.

Song $1 \mathrm{H}$, Xuan NT, Toan NL, Binh VQ, et al. (2008). Association of two variants of the interferon- $\alpha$ receptor-1 gene with the presentation of hepatitis B virus infection. Eur. Cytokine Netw. 19: 204-210.

Thio CL, Mosbruger TL, Kaslow RA, Karp CL, et al. (2004). Cytotoxic T-lymphocyte antigen 4 gene and recovery from hepatitis B virus infection. J. Virol. 78: 11258-11262.

Tseng LH, Lin MT, Shau WY, Lin WC, et al. (2006). Correlation of interleukin-10 gene haplotype with hepatocellular carcinoma in Taiwan. Tissue Antigens 67: 127-133.

Wang C, Tang J, Song W, Lobashevsky E, et al. (2004). HLA and cytokine gene polymorphisms are independently associated with responses to hepatitis B vaccination. Hepatology 39: 978-988. 
Wu JF, Wu TC, Chen CH, Ni YH, et al. (2010). Serum levels of interleukin-10 and interleukin-12 predict early, spontaneous hepatitis B virus e antigen seroconversion. Gastroenterology 138: 165-172.

Yan Z, Tan W, Zhao W, Dan Y, et al. (2009). Regulatory polymorphisms in the IL-10 gene promoter and HBV-related acute liver failure in the Chinese population. J. Viral Hepat. 16: 775-783.

Yoshida K, Alagbe O, Wang X, Woolwine B, et al. (2005). Promoter polymorphisms of the interferon- $\alpha$ receptor gene and development of Interferon-induced depressive symptoms in patients with chronic hepatitis C: preliminary findings. Neuropsychobiology 52: 55-61.

Zhou J, Huang JD, Poon VK, Chen DQ, et al. (2009b). Functional dissection of an IFN- $\alpha / \beta$ receptor 1 promoter variant that confers higher risk to chronic hepatitis B virus infection. J. Hepatol. 51: 322-332.

Zhou J, Smith DK, Lu L, Poon VK, et al. (2009a). A non-synonymous single nucleotide polymorphism in IFNAR1 affects susceptibility to chronic hepatitis B virus infection. J. Viral Hepat. 16: 45-52. 